\title{
Egyetemek a régiók versenyképességének javításáért: „negyedik generációs” egyetemek?
}

\section{Universities enhancing regional competitiveness: "fourth generation" universities?}

\author{
LUKOVICS MIKLÓS, ZUTI BENCE
}

LUKOVICS Miklós: docens, Szegedi Tudományegyetem, Közgazdaságtani és Gazdaságfejlesztési Intézet; miki@eco.u-szeged.hu

ZUTI Bence: MSc-hallgató, Szegedi Tudományegyetem Gazdaságtudományi Kar; zuti.bence@gmail.com

KULCSSZAVAK: egyetem, gazdaságfejlesztés, rombuszmodell

ABSZTRAKT: Napjainkban igen sok sikeres példa bizonyítja, hogy az egyetemek komoly szerepet tölthetnek be egy-egy térség versenyképességének javításában. A modern gazdasági fejlődés megkívánja, hogy a fokozott társadalmi és gazdasági szerepvállalás következtében az egyetem tradicionális (oktatási és kutatási) tevékenységei kibővüljenek. Ahhoz ugyanis, hogy az egyetemek képesek legyenek gazdaságfejlesztési potenciáljuk optimális kihasználására, szükséges, de nem elégséges az oktatás magas színvonala. Szükség van magas színvonalú kutatásra is, és arra, hogy mindezen eredményeket a helyi gazdaság hasznosítsa. A fenti folyamatokat leíró közismert első, második és harmadik generációs egyetemi modelleken túl a nemzetközi szakirodalomban megjelent a „negyedik generációs” egyetem kifejezés is, melyről a tudományos közösségben ugyan még nincs konszenzus, de mindenképen érdekes és megfontolandó gondolatokat vet fel az egyetemek helyi gazdaságfejlesztési szerepvállalásáról.

Jelen tanulmány célja az, hogy áttekintse és rendszerezze az egyetemek azon aktív és passzív tevékenységeit, amelyek az adott térség versenyképességének javítását szolgálják. Körüljárjuk a „negyedik generációs” egyetemek mibenlétét, és kísérletet teszünk arra, hogy azokat az egyetemi generációk tudományosan igazolt fogalomrendszerébe helyezzük. Megvizsgáljuk továbbá, hogy megadhatóak-e olyan sikerességi faktorok, „építőkövek”, amelyek mentén a nemzetközileg sikeres, a helyi gazdasági fejlődésre jelentős hatást gyakorló egyetemek jellemezhetőek.

Miklós LUKOVICS: associate professor, Institute of Economics and Economic Development, University of Szeged; miki@eco.u-szeged.hu

Bence ZUTI: MSc student, Faculty of Economics and Business Administration, University of Szeged; zuti.bence@gmail.com

KEYWORDS: university, economic development, diamond-model

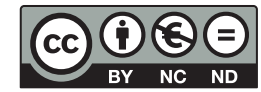


ABSTRACT: Many successful examples prove that universities can have a significant role in the enhancement of their regions. Modern economic development demands that due to increased committment to the needs of society and economy, the main traditional activities of universities (education and research) should be broadened and diversified. To be able to optimally exploit their potential regarding regional economic development, the presence of an outstanding educational culture is necessary but not sufficient. It is also necessary to maintain high quality standards regarding research activities and to promote the utilisation of research results among local actors and the local economy (spin-offs).

Beyond the well-known typology of the first, second and third generation of universities that describes the above mentioned processes, the concept of the "fourth generation" of universities emerged in international literature although it has not become a topic of general consensus of the scientific community yet. However, it describes interesting facts that are worth considering regarding the economic development effects of universities.

We concluded that the most significant distinguishing characteristic is proactivity. Its purpose is to initiate and influence changes in local society and economy in accordance with the demands of a knowledge-based society.

The logic of "fourth generation" universities goes beyond the logic of third generation of universities in that "fourth generation" universities would play a larger role in affecting the local area, i.e. they should be able to form their social and economic environment, instead of just answering to local needs.

This approach involves the enhancement of strategic aspects and the spread of an innovative and flexible organisational culture. In the case of "fourth generation" universities, besides the education-research-knowledge utilisation triangle, the goal is to prepare for the conscious, planned, future-oriented development of a local economy. In this model, the university is the catalyst and one of the engines of the economy at the same time. It not only contributes to the education of professionals, scientists, entrepreneurs, but also to the formation of their environment. In the case of "fourth generation" universities, multilingual operations may be necessary due to cross-border cooperations and the presence of other network connections. A professional management will be responsible for strategic and operative activities, although local experts and professionals also have a significant role in these actions.

This study aims to review and systematise the active and passive activities of universities that can enhance the competitiveness of any given region. We review the available ideas regarding the presence of "fourth generation" universities and we attempt to integrate these into a scholarly grounded framework of university generations. Furthermore we identify and examine the potential existence of success factors or "components" that may generally characterise internationally successful universities with a notable local economic impact.

\section{Bevezetés}

Több nemzetközi példa bizonyítja, hogy a sikeres egyetemek komoly szerepet tölthetnek be térségük versenyképességének javításában, és sok esetben aktív szereplői a helyi gazdaságfejlesztési erőfeszítéseknek. Annak érdekében, hogy az egyetemek képesek legyenek gazdaságfejlesztési potenciáljuk betöltésére, szükséges, de nem elégséges az oktatás magas színvonala (első generációs egyetemi funkciók). Szükség van magas színvonalú kutatásra is (második generációs egyetemi funkciók), és arra, hogy mindezen eredményeket a helyi gazdaság szereplői hasznosítsák (harmadik generációs egyetemi funkciók). Ezen keresztül ugyanis nő a helyi vállalkozások versenyképessége, ami a térség ver- 
senyképességének növekedésével járhat együtt. Jogosan merülhet fel a kérdés, hogy azon esetekben, amikor az egyetem gazdaságfejlesztési szerepe olyan aktív gazdaság- és térszervező funkciót jelent, amely a fentieken túllépve stratégiai szemléletben még ki is jelöli egy-egy térség gazdasági irányvonalait, az hogyan illeszthető ebbe a tipológiába.

A térségek versenyképességét a globalizáció mellett napjainkban egyéb háttérfolyamatok is befolyásolják, átalakítják, amelyekre mint térszervező erőkre érdemes és kell is figyelni. A globális versenyben a nem tárgyi javak, mint például a tudás vagy a kapcsolati tőke váltak kulcsfontosságú tényezőkké, a gazdasági fejlődés legfontosabb mozgatórugóivá. A regionális tudományban a tudást mint a regionális fejlődés meghatározó tényezőjét azonosítják. A termelés fö erejévé a tudás vált, a tudást a gazdasági növekedés újfajta motorjaként foghatjuk fel, ezáltal a tudásnak, az innovációnak, a technológiának és a tanulásnak a gazdaságban betöltött szerepét újra kell gondolni. Ez abból is következik, hogy az innovációk jelenléte a térségek versenyképességét alapvetően meghatározza, és folyamatos innováció szükséges a versenyelőnyök eléréséhez (Lengyel I. 2000a). Az innováció azonban másképpen van jelen a különböző fejlettségü térségekben, ezért fontos, hogy az eltérő fejlettségü térségekben más és más gazdaságfejlesztési stratégiákat kell alkalmazni (Lengyel I. 2003). Mindezekből az is következik, hogy a fejlett gazdaságok versenyelőnye elsősorban azok tudás-előállítási és tudáshasznosítási képességein nyugszik (Grosz, Rechnitzer 2005). E folyamatok alakításában nagy szerep jut az egyetemeknek is, oktató és kutató funkciójuk kibővül a gazdasági és társadalmi fejlődés tudatos elősegítésével (Etzkowitz 2002; Wissema 2009; Wright, Clarysse, Lockett, Knockaert 2008).

Tanulmányunkban a fenti kihívások alapján arra az alapkérdésre keressük a választ, hogy mit tehetnek az egyetemek (akár aktívan, akár passzívan) annak érdekében, hogy térségük versenyképessége növekedjék. E kérdés megválaszolásához először megvizsgáljuk az egyetemek lokális beágyazódásának kereteit. Ezt követően körüljárjuk az egyetemek potenciális gazdaságfejlesztési hatásait, input- és outputoldalú vonzatait. Az egyetemek társadalmi-gazdasági környezetének elemzését egy újfajta gondolatkísérleten keresztül, a „negyedik generációs” egyetemi funkciók gondolatkörében végezzük el a modern egyetemek rombuszmodellje segítségével. Végül megkíséreljük megadni azon építőköveket, sikerességi faktorokat, melyek hozzájárulhatnak ahhoz, hogy az egyetemek a lokális tér lehetőségeit optimalizálva képesek legyenek javítani térségük versenyképességét.

\section{Az egyetemek lokális beágyazódásáról}

A helyi gazdaság iránti elköteleződésnek egyre hangsúlyosabb szerepe van a modern egyetemek múködése során, hiszen új társadalmi és gazdasági igények 
törnek felszínre. Számos gazdasági, pénzügyi és társadalmi körülmény változása vezetett oda, hogy az egyetemek új, nyitottabb szemléletben kezdték feltérképezni környezetüket, elkötelezték magukat a lokális beágyazódás, az innovációs tevékenységek előmozdítása, valamint a helyi szereplőkkel való intenzívebb együttműködés iránt. Az ilyen típusú egyetemek létrejötte adaptív folyamat eredménye. Az adaptivitás ebben az esetben kulcsképesség, hiszen globális szinten is számos olyan, nemzeti vagy regionális szinteket érintő intézkedés mehet végbe, ahol a megváltozott körülményekhez való gyors és hatékony alkalmazkodásnak döntő szerepe van a jövőt illetően (Clark 1998).

Clark (2001) „vállalkozói” egyeteme döntően abban különbözik a „hagyományos" egyetemtől, hogy utóbbi nem tud kitörni a megszokott, kőbe vésett gyakorlatokból, míg az előbbi törekszik tevékenységei és gyakorlatai terén a megújulásra, a kortárs szemléletmód követésére. Amellett, hogy a vállalkozói egyetem felfedező természetű, jövőbe tekintő, erős identitással rendelkező intézmény is. A vállalkozói egyetem alapját többnyire a menedzsmentszemléletű vezetés és az adott piaci sajátosságok minél nagyobb mértékủ kiaknázása adja.

Chatterton és Goddard (2000) ezzel párhuzamosan a regionálisan elkötelezett egyetemekről ír. Alapvetően a szerzők ezt az egyetemtípust a tanuló régiókon belül helyezik el. Ezekben a térségekben kiemelt hangsúlyt kap a tanulási folyamat, valamint a dinamikus tervezési szemlélet (Holbrook, Wolfe 2002). A tanuló régió nagyban különbözik azoktól a térségektől, melyekben a fordista szemlélet a domináns, hiszen a versenyképesség alapját nem a természeti erőforrások és a fizikai munkaerő adja, hanem a tudásteremtés és a folyamatos fejlődés. A tanuló régiókra jellemző a hálózatok, a kooperáción és tudásmegosztáson alapuló formális vagy éppen informális kapcsolatrendszerek jelenléte (Florida 1995, 533.). Kitagawa (2005) is a formális és informális tényezők tudatos formálásában és erősítésében látja a gazdaságfejlesztés lényegét, ugyanakkor kiemeli azt, hogy ez a tevékenység akkor lehet sikeres és hatékony, ha a tudástranszfer akadálymentes az érintett intézmények között. A regionális szinten elkötelezett egyetemek továbbá nagyban építenek arra, hogy bekapcsolják az oktatási, kutatási és harmadik missziós tevékenységeket a régió gazdaságának vérkeringésébe, ezáltal létrehozva hozzáadott értéket. Napjaink egyetemei lokálisan beágyazottak, ám adott esetben globális szinten küzdenek az erőforrások megszerzéséért.

Bármelyik előbb említett egyetemtípust vizsgáljuk, a törekvéseik egyértelműen leképezhetők, a működési keret határozottan megadható. A cél annak elkerülése, hogy a felsőoktatási intézmények a helyi gazdaságban elszigetelten működjenek, emellett fontos szempont annak elérése, hogy a kutatási eredményeket a helyi gazdaság hasznosítani tudja. Távlatokban az egyetemek a helyi közösségek egyik legfontosabb szereplőiként a fejlődési folyamatok előmozdítását hivatottak segíteni (Arbo, Benneworth 2007; Benneworth, Dawley 2005).

Goddard és Puukka $(2008,19$.) szerint a felsőoktatási intézmények a gazdaságfejlesztéshez négy főbb módon képesek hozzájárulni. Elsőként az egyetemek hozzájárulhatnak új szektorok megteremtéséhez vagy a meglévők alakításához, 
ösztönző szerepkör juthat nekik a vállalkozások létrehozásában. Másodszor, a meglévő kiváló infrastrukturális körülmények, a magasan képzett munkaerő, az erős gazdasági és társadalmi hálózatok meglétével képesek vonzani nagy, adott esetben külföldi székhelyü cégeket. Ebben az esetben is megjelenik a lokális elköteleződés mellett a globális szinten zajló verseny az erőforrásokért, tőkéért. Harmadszor, képesek az üzleti szektor diverzifikálására, az általuk létrehozott termékek, az általuk nyújtott szolgáltatások minőségének fejlesztésére. Negyedszer, stratégiai szemlélet mentén a térség domináns iparágainak folyamataiba is képesek bekapcsolódni, akár tanácsadás, akár bizonyos folyamatok hatékonyabbá tétele révén.

\section{Az egyetemek gazdaságfejlesztési hatásairól}

Az egyetemek helyi gazdasági hatásait két csoportba sorolhatjuk (Lengyel I. 2008): inputoldali rövid távú hatásokra és outputoldali hosszú távú hatásokra (1. ábra). Az egyetem saját épületeinek fenntartására és üzemeltetésére jelentős összegeket költ. Ezeket a szolgáltatásokat a helyi vállalkozásoktól rendeli meg. Az egyetemi hallgatók, az oktató és kutató munkatársak szintén helyben költik el jövedelmük bizonyos részét. Az egyetem jelenléte ösztönzi a helyi szolgáltatásokat, mindez gyarapítja a helyi önkormányzat bevételeit, de egyúttal a keresletet is a közszolgáltatások iránt.

Az egyetem rövid távú hatásai (inputoldal) befolyásolják a helyi vállalkozások keresletét, a helyi háztartások bevételeit és kiadásait, valamint a helyi önkormányzat szolgáltatásait és bevételeit.

1. ábra: Az egyetemek helyi gazdasági hatásai Local economic effects of universities

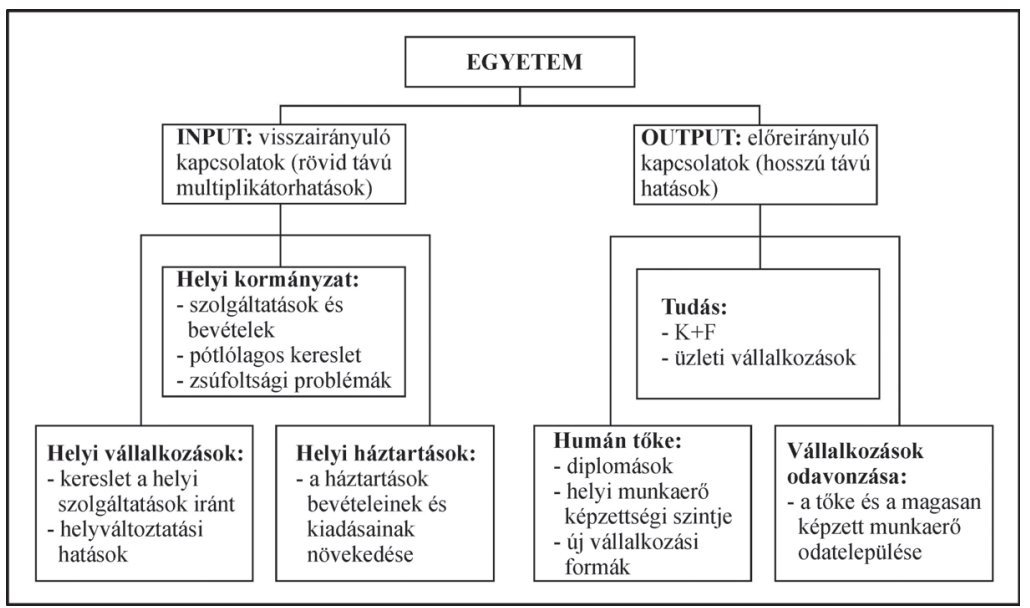

Forrás: Lengyel I. (2008). 
Az egyetemeknek köszönhetően évről évre fiatal szakképzett diplomások sokasága jelenik meg a munkaerőpiacon. A helyi munkaerő az újonnan megszerzett készségeknek és képességeknek köszönhetöen könnyebben indíthat új vállalkozásokat, vagyis az oktatási intézmények megnövelhetik a vállalkozói kedvet. A friss diplomás álláskeresők a térségen kívülről vállalkozásokat csábíthatnak a régióba, ami új munkahelyek létesüléséhez vezet. Az egyetem oktatói és kutatói jelentős K+F-tevékenységet folytatnak (Lengyel I. 2008).

Az egyetem hosszú távú hatásai (outputoldal) hatással vannak a humán tőke képzettségére, a külföldi tőke és munkaerő egyetem térségébe való betelepülésére, valamint az egyetemi kutatásokon alapuló üzleti vállalkozásokra.

Az inputoldali tényezők a gazdasági bázismodellben a másodlagos regionális multiplikátorhatások kiváltói, mivel a helyi szolgáltatások iránti keresletet élénkítik. Azonban ez a kereslet érdemi gazdasági növekedést nem generál, és új munkahelyeket alig hoz létre.

Az outputoldali tényezők az elsődleges regionális multiplikátorhatások gerjesztői. Olyan új cégek jöhetnek létre, alakíthatnak ki új munkahelyeket a régióban, amelyek a térségen kívülről szerzik jövedelmeiket.

Goldstein és Renault (2004) célja, hogy felmérjék az egyetemek hozzájárulásának mértékét a regionális gazdasági fejlődéshez, továbbá hogy megpróbálják elkülöníteni az egyetemek funkcióinak gazdasági hatásait. Az elemzés egysége az Egyesült Államok 312 statisztikai nagyvárostérsége az 1969-1986 és az 1988-1998 közötti periódusokra. A regionális gazdaságfejlesztés mértékegysége az egy főre jutó éves átlagkereset. Azért, hogy kiküszöböljék a makroökonómiai változásokat, minden térségben elosztották az átlagos kereseteket az Egyesült Államok azonos évre vonatkozó átlagos kereseteivel. A függő változót ezt követően képezték két egymást követő év indexének különbségével.

Az egyetemek térségi jelenlétét négy változóval mérték. Az első, hogy a térségben van-e olyan egyetem, amely a legjobb 50 kutatóegyetem közé sorolható a megfelelő periódusban. A második változó a kutatási ráfordítások összege a térség egyetemein, adott évben. A harmadik változó a térség felsőoktatási intézményeiben átadott diplomák száma évenként. A negyedik az egyetemeknek tulajdonított szabadalmak száma a térségben.

A szerzők kontrollváltozókat is választottak, amelyek segíthetnek megmagyarázni a régió gazdasági jólétében bekövetkező változásokat. Ilyenek voltak a foglalkoztatottság nagyságát reprezentáló térségtípus (kis, közepes, nagy), a térség földrajzi fekvése (Északkelet, Középnyugat, Dél, Nyugat), gazdasági szerkezete (feldolgozóipar, szolgáltatások), megközelíthetősége (nagy, közepes vagy kis méretű repülőtér), vállalkozói tevékenysége (jövedelmek, szabadalmak) és az átlagkeresetek bázisévi szintje.

A vizsgálat eredményeképpen az alábbi következtetésekre jutottak. A kutatóegyetemek jelentősen hozzájárulnak a gazdasági fejlődéshez a második periódusban. A két periódus között kezdte el éreztetni hatását az Egyesült Államokban 1980-ban elfogadott Bayh-Dole törvény, amely lehetővé tette, hogy az egyete- 
mek a közfinanszírozású kutatási eredményeik felett szellemi tulajdonjogokat gyakoroljanak. A kutatás-fejlesztési tevékenység intenzívebben serkenti a gazdaságot, mint a szabadalmaztatás vagy a licenctevékenység. Bár a szabadalom a gazdasági hasznosuláshoz közelebbi kategória, mégis a kutatás-fejlesztési ráfordítás a szignifikáns befolyásoló tényező. Mivel a felhalmozódó tudás számos csatornán keresztül jut a gazdaságba, így a K+F-ráfordításoknak összességében van hatása, akár informális csatornákon keresztül is. Negatív kapcsolatot fedeztek fel a diplomások munkaerőpiacán, mivel az utóbbi periódusban az telítettséget mutatott. Minél nagyobb a diplomások száma, annál kisebbek a jövedelmek, ami annak köszönhető, hogy a diplomások egymás esélyeit rontják, és így leverik a béreket.

Goldstein és Renault módszertanát a magyar kistérségekre alkalmazta Bajmócy Zoltán, Lukovics Miklós és Vas Zsófia (2009). Megállapították, hogy a magyar kistérségekre nem igazolhatók Goldstein és Renault megállapításai, és hazánkban az egyetemek helyi innovációs hatásai nem szignifikánsak.

Az egyetemek és kutatóintézetek közvetve és közvetlenül is jelentős befolyással lehetnek egy térség fejlödésére és versenyképességére, valamint gyakran fogalmazódik meg az, hogy az egyetem oktatási és kutatási funkciója csak az eredmények gazdasági hasznosulásával együtt tud hatékonyan kiteljesedni és gazdasági hatásokat eredményezni (Bajmócy 2006).

Wissema (2009) szerint napjainkban az egyetemek második nagy átalakulási folyamata zajlik (1. táblázat). Az egyetemek ebben az új fázisban nem csupán szakembereket és tudósokat (első és második generációs egyetemek), hanem szakembereket, tudósokat és vállalkozókat képeznek (harmadik generációs egyetemek).

Megállapíthatjuk, hogy egy térség versenyképességének javítását elsősorban a harmadik generációs egyetemektől várhatjuk, hiszen ez az a szakasz, ahol az egyetemek nem csupán oktatnak és kutatnak, hanem a tudáshasznosulás is döntő szempont működésükben. Mindez azt eredményezi, hogy a gazdaság és az egyetem szoros kapcsolatba kerül, melyen keresztül lehetőség nyílik az egyetemen

1. táblázat: Az első, második és harmadik generációs egyetemek néhány jellemzője Some characteristics of the first, second and third generations of universities

\begin{tabular}{llll}
\hline Megnevezés & Első generációs egyetemek & Második generációs egyetemek & $\begin{array}{c}\text { Harmadik generációs } \\
\text { egyetemek }\end{array}$ \\
\hline Cél & Oktatás & Oktatás és kutatás & $\begin{array}{l}\text { Oktatás, kutatás és } \\
\text { tudáshasznosítás }\end{array}$ \\
\hline Szerep & Az igazság védelme & A természet megismerése & Értékteremtés \\
\hline Létrehoz & Szakembereket & $\begin{array}{l}\text { Szakembereket és } \\
\text { tudósokat }\end{array}$ & $\begin{array}{l}\text { Szakembereket, tudósokat } \\
\text { és vállalkozókat }\end{array}$ \\
\hline Nyelv & Latin & Nemzeti & Angol \\
\hline Menedzsment Kancellár & Részmunkaidős tudósok & $\begin{array}{l}\text { Professzionális } \\
\text { menedzsment }\end{array}$ \\
\hline
\end{tabular}

Forrás: Wissema (2009) alapján saját szerkesztés. 
képződött tudás helyi felhasználására, ami a vállalkozások versenyképességének javulásán keresztül javítja a térség versenyképességét (Vilmányi 2011).

A harmadik missziós tevékenységnek egyedül akkor van értelme, ha a szóban forgó egyetem aktív szereplője a helyi közösségnek és képes sikeresen beágyazódni a helyi gazdaságba (Benneworth, Sanderson 2009).

\section{Az egyetemek gazdasági és társadalmi környezete}

A tudásalapú társadalom szükségszerűen hozza magával a humán erőforrások jelentőségének felértékelését, mivel a gazdaságok versenyképessége nagymértékben függ a rendelkezésre álló humán erőforrások mennyiségi és főként minőségi jellemzőitől. A rendelkezésére álló humánerőforrás-állomány képzésének kulcselemei az egyetemek, melyek egyre fontosabb szerepet töltenek be a fejlett gazdaságokban.

Regionális szinten jellemző, hogy fokozottan felértékelődnek az egyetemek köré szerveződő kooperációs hálózatok. A klasszikus triple helix (újabban quadruple helix) koncepció egyik fó gondolata, hogy adott régióban az egyetem-gazdaság-kormányzat háromszög szereplői bár megtartják alapvető tevékenységköreiket, elképzelhető, hogy bizonyos funkciókban osztoznak egymással, átfedés alakul ki (Etzkowitz 2002, 2008; Etzkowitz, Leydesdorff 2000; Lengyel B. 2004). A triple helix modell kapcsán mindig ki kell emelnünk a tudástranszfer fontosságát, ugyanakkor az egyetemnek mint aktornak komoly funkciója van regionális, társadalmi és gazdaságfejlesztési szemszögből is (Gibb, Haskins, Robertson 2013), mely megközelítést társadalmi fókusza miatt a quadruple helix gondolata felerősíti (Carayannis, Rakhmatullin 2014). Az egyetemek a munkahelyteremtő szerep mellett tőkét is képesek vonzani, továbbá közvetítő szerepkört is betöltenek a kormányzat felé történő kommunikációban (Imreh-Tóth, Lukovics 2014).

Az egyetemeknek tehát szoros együttműködést kell kialakítaniuk egyrészt a gazdaság szereplőivel, másrészt a kormányzati szervekkel, harmadrészt a helyi gazdasággal és társadalommal. Erre szükség van, hiszen egy térség szereplőinek minél szorosabb összefogása nélkülözhetetlen a területi fejlődés szempontjából (Lengyel I. 2004). Az egyetem és a piacorientált szféra szoros kapcsolata révén ugyanis lehetővé válik az egyetemen képződött tudás adott térségben történő felhasználása, ami javíthatja a helyi vállalkozások versenyképességét, ezen keresztül pedig az adott térség versenyképességét (Lukovics 2010). Napjainkban egyre több felsőoktatási intézmény kíván részt venni ebben a folyamatban, környezetükben kialakított kapcsolatokkal ösztönözni a fejlesztési folyamatokat, mintegy központi húzóerőként.

Egyre elterjedtebb azonban a felfogás, miszerint a triple helix koncepció további spirálokkal bővíthető. Ennek értelmében akár negyedik vagy éppen 
ötödik spirál jelenlétéről is beszélhetünk. A szakirodalom negyedikként a média, a civil társadalom és a művészetek, ötödik spirálként a természeti, környezeti, valamint fenntarthatósági aspektusok jelentőségét tartja számon az innovációs és tudásteremtési folyamatokban (Carayannis, Campbell 2012, 2014).

A fenti logikát folytatva a következő lépés az, hogy az egyetemek gazdasági és társadalmi környezetét megpróbáljuk logikai rendszerbe foglalni. Ehhez kiváló analógiát kínál a vállalatok mikroökonómiai üzleti környezetét rendszerező Porter-féle rombuszmodell (Lengyel I. 2000b). Az eredeti Porter-rombusz tényezőit leképezhetjük egyetemi kontextusban is. Így definiálhatjuk, melyek azok a tényezők, amelyek hosszú távon is versenyelőnyhöz juttathatják az egyetemeket, az eredeti logika szerint nemzetközi versenykörnyezetet feltételezve (2. ábra). Az összetevők az egyetemi dimenzióban történő leképezéssel új tartalommal töltődnek fel.

2. ábra: A modern egyetemek rombuszmodellje The diamond model of modern universities

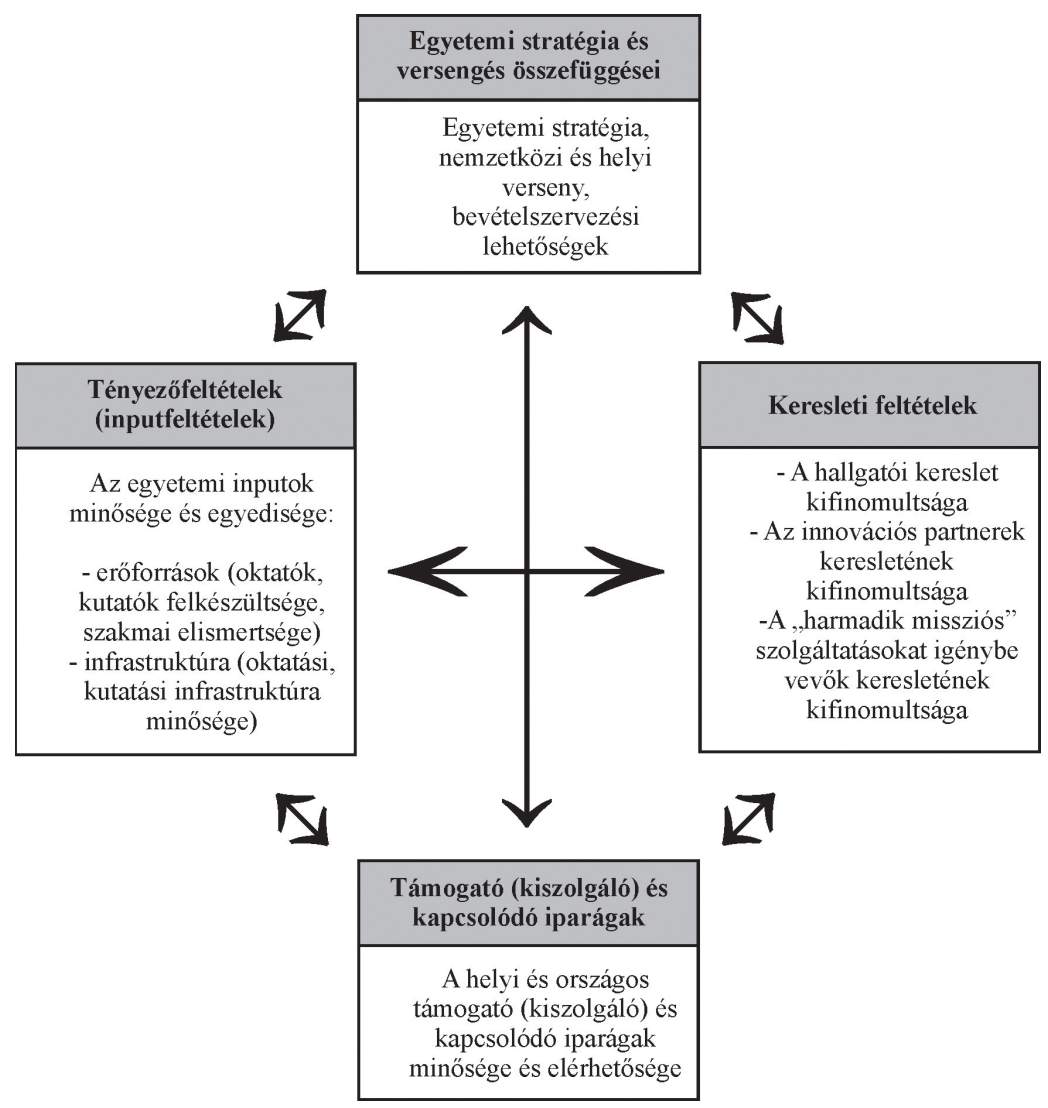


A tényezőfeltételek kapcsán az egyetemek szempontjából is a humán erőforrásnak és az infrastruktúrának van a legfontosabb szerepe, tehát itt hard és soft jelleg egyaránt tükröződik. Ebben az alkotóelemben kapnak helyet azon tényezők, melyek az alapját jelentik az egyetem potenciális versenyképességének. Minél képzettebb, felkészültebb az oktatói-kutatói gárda, minél korszerủbb az infrastruktúra, annál jobb helye lehet egy egyetemnek a képzeletbeli globális ranglétrán. A tényezőfeltételek között döntően első és második generációs egyetemi funkciók kapnak helyet, azonban a kutatási háttérinfrastruktúrában implicite a harmadik generációs jelleg is helyet kap abban az értelemben, hogy a fejlett kutatási infrastruktúrára és kutatói felkészültségre támaszkodva a sikeres egyetemek a publikációs outputokon túlmenően piacilag hasznosítható kutatási eredményeket hoznak létre.

A keresleti feltételeken minden olyan tényező iránti keresletet értjük, amelyek az egyetem tevékenységének outputját képezik. A helyi szintű igényes kereslet állandó fejlődésre készteti az egyetemeket mind oktatási, mind kutatási, mind harmadik missziós területen, ami állandó minőségi javulást eredményez, mely a nemzetközi versenyképesség szükséges, de nem elégséges feltétele. Harmóniában az inputoldallal természetesen az is fontos, hogy outputoldalon magasan képzett, magas szintű ismeretekkel rendelkező diplomások kerüljenek a munkaerőpiacra. A keresleti feltételek mind mennyiségi (hallgatók kritikus tömege), mind minőségi (megfelelés a hallgatói elvárásoknak) dimenziókat magukban rejtenek, emellett napjainkban már fontos a legkiválóbb hazai és külföldi hallgatók vonzása is. Ezen a ponton külön ki kell emelnünk az egyetemek gazdaságfejlesztési funkcióit, amely az erre vonatkozó helyi kereslet függvényében különböző formákat ölthet: fejlett térségekben az egyetem aktív szereplője a helyi gazdasági folyamatoknak és integránsan illeszkedik a helyi gazdaságba. Hallgatólagosan feltételezzük, hogy ilyen esetekben a fejlett térségek gazdasági szerkezete már markánsan kialakult, és az egyetem mind oktatási, mind kutatási, mind harmadik missziós tevékenységével ehhez a struktúrához illeszkedve aktívan részt vesz a helyi gazdasági vérkeringésben. Fejletlen térségekben ezzel szemben az egyetemeknek azzal a kihívással is szembesülniük kell, hogy a helyi gazdasági szerkezet markáns jellege még nem alakult ki (ugyanez igaz gazdasági szerkezetátalakítás folyamatában levő térségekben). Ilyen esetekben az egyetemek többletfunkciója kell legyen az, hogy proaktív módon a helyi gazdasági folyamatok élére állnak és a helyi gazdaságfejlesztés zászlóshajójává válnak.

A támogató és kapcsolódó iparágak jelentik mindazon partnereket, melyek közvetve vagy közvetlenül befolyással vannak az egyetem sikerességére. Az egyetemek jellemzően az üzleti szférával, valamint egyéb egyetemekkel, kutatóintézetekkel építenek ki tartós és szoros kapcsolatot.

Az egyetemi stratégia és verseny összefüggéseiben alapfeltétel, hogy az intézményi dokumentumok és stratégiák összhangban legyenek a helyi közeg sajátosságaival, hiszen ez is kritikus pont a sikeresség szempontjából. 


\section{A „negyedik generációs” egyetemek}

Az egyetemek rombuszmodelljében már megjelent néhány olyan funkció, mely a harmadik generációs funkciók hagyományos értelmezésén túlmutat. A nemzetközi szakirodalomban megjelent a „negyedik generációs” egyetem kifejezés, de a tudományos közösség szakmai konszenzusa még nem jött létre a fogalomról. A kifejezés arra utal, hogy napjaink modern egyetemeinek a kiélezett globális versenyben sok esetben arra is képeseknek kell lenniük, hogy proaktívan befolyásolják térségük gazdasági és társadalmi folyamatait. E folyamatok és hatások azonban közvetlenül vagy közvetetten, sokszor bonyolult áttételeken keresztül javítják egy-egy térség versenyképességét, eltérő versenyképességű régiók eseteiben más és más módon.

Annak vizsgálatára, hogy kifejezetten elmaradott térségben az egyetemek milyen módon tudnak a helyi gazdaságfejlesztésre proaktívan hatni, talán a fentebb említett „negyedik generációs” funkciók gondolata adhat egyfajta választ. Kiemelheto", hogy amikor az egyetem elmaradott térségek gazdaságfejlesztésében betöltött szerepéről beszélünk, a „negyedik generációs” jelző kissé félrevezető lehet, amennyiben a harmadik generációs egyetemek egyfajta továbbfejlesztését várjuk tőle. Tartalmát tekintve inkább a klasszikus triple helix modell egyetem helixének hangsúlyosabb szerepéről beszélhetünk (ImrehTóth, Lukovics 2014), hiszen az egyetem ez esetben szükségszerüen domináns szerepben van a helyi gazdaság többi szereplője között. Ezt a témakört, következésképpen az elnevezést sem tekintjük még tudományosan alátámasztott tételnek, viszont logikája nagymértékben előmozdíthatja gondolkodásunkat az elmaradott térségben megvalósuló egyetemközpontú gazdaságfejlesztésről. Krzysztof Pawlowski (2009) tanulmányát gondolatébresztőnek és vitaindítónak tekinthetjük ebben a témában. A szerző a „negyedik generációs” egyetem hatását vizsgálta a lokális fejlődésre. Cikkében egy lengyelországi egyetemet mutat be, a Nowy Sącz székhelyü WSB-NLU-t, amely Małopolskie NUTS2-es régióban található, ahol az egy före jutó GDP az EU-28 átlagának 56\%-a (Eurostat 2014), így megállapításai különösen érvényesek az elmaradott térségekre. Arra a következtetésre jutott, hogy ezen egyetemek legfőbb megkülönböztető ismérve a proaktivitás, amellyel a felsőoktatási intézmény alapvető célja az, hogy döntő mértékben befolyásolja lokális térségének gazdasági-társadalmi változását, a tudásalapú gazdaság igényeinek megfelelően.

A „negyedik generációs” egyetemek logikája tehát annyiban mutat túl a harmadik generációs egyetemekén, hogy nagyobb szerep jut az egyetemnek a helyi gazdaságra és társadalomra való hatására: a „negyedik generációban” már ahelyett, hogy igyekezne minél inkább megfelelni a helyi gazdaság és társadalom támasztotta igényeknek, az egyetem maga alakítja társadalmi és gazdasági környezetét.

A negyedik generációs egyetemek társadalomra való hatásgyakorlása kapcsán ki kell emelnünk a felelelősségteljes innováció témakörét, mint egy olyan funkciót, melyet egyértelműen negyedik generációs jellegként foghatunk fel. 
Igaz ugyan, hogy a kutatás-fejlesztés és az innováció az ugrásszerủ fejlődés ígéretét hordozza magában, azonban ehhez etikai dilemmák és előre meg nem jósolható hatások kockázatai is szorosan kapcsolódhatnak (Sutcliffe 2013; Von Schomberg 2013). E hatások kiküszöbölése sok esetben csak tényleges megjelenésük után lehetséges, a beavatkozás ezen időpontban viszont sok esetben már elkésett és igen költséges. A kihívásra való lehetséges preventív válaszként fejlődött ki a felelősségteljes kutatás és innováció (responsible research and innovation, RRI) kérdésköre. A felelősségteljes kutatás és innováció elmélete arra próbál válaszokat keresni, hogy hogyan lehetünk képesek a kutatás-fejlesztési és innovációs tevékenységek felelősségteljes folytatására a felgyorsult világban úgy, hogy az nemcsak a társadalmilag elfogadott, de a társadalmat előremozdító innovációs célokat is szolgálja, fenntartható, demokratikus és igazságos módon (Owen, Macnaghten, Stilgoe 2012; Sutcliffe 2013; Von Schomberg 2013) - ez az innovációs cél pedig helyi gazdasági és társadalmi vezető szerepe által a negyedik generációs egyetemek egyik fó funkciójává válhat. A felelősségteljes kutatás és innováció témaköre világszerte kurrens témának tekinthető, napjainkra az Európai Unió innovációpolitikáját is egyre erőteljesebb mértékben befolyásolja (EC 2013a, 2013b).

A „negyedik generációs” szemléletben fontos szerepe van a stratégiai szemlélet erősödésének, valamint az innovatív, rugalmas szervezeti kultúra térhódításának. Napjainkban már szinte minden akörül forog, hogy hatékonyan tervezzük a jövőt, stratégiai szemléletben gondolkodjunk. Az egyetemek több szempontból is egyre inkább rákényszerülnek a proaktív jellegre. Fejletlen térségek egyetemei sok esetben kénytelenek váltani, hiszen a megváltozott forrásabszorpciós körülmények miatt kénytelenek profilt bővíteni, méghozzá olyan tevékenységekre összpontosítva, melyek pótlólagos forrást biztosítanak akár állami (nemzeti és EU-s pályázatok), vállalati (tudástranszfer-tevékenység, szabadalmak piacosítása), akár társadalmi aspektusból (kulturális tevékenységek, rendezvények). Mindezek sikeréhez elengedhetetlen a sok esetben lomha, rugalmatlan szervezeti kultúra kereteinek szétfeszítése.

A „negyedik generációs” egyetem lényegét úgy is megfogalmazhatjuk, hogy a társadalom, a gazdaság, a globalizációs folyamatok és az információs technológiák olyan korszakába értünk, ahol a stratégiai szemlélet jelenléte létfontosságú kérdés. Az egyetemeknek manapság még inkább tudniuk kell pozicionálni magukat lokális, regionális, nemzeti és globális szinten. Fontos a kiváló munkaerő létrehozása, az innovációk piacosításának képessége és különböző léptékeken történő adaptációjuk, valamint a hálózatok komplex rendszerének megléte. A triple helix-típusú kapcsolatrendszerek kedvező kimenetelű folyamatokat katalizálhatnak az aktorok bármelyikének szemszögéből, így a kooperációk feltehetően egyre sürüsödnek.

A Wissema-féle csoportosítás logikáját követve szemléltetni tudjuk a „,negyedik generációs" egyetemek jellemzőit, ezzel új szintre kiegészítve az 1. táblázat tipológiáját (2. táblázat). A „negyedik generációs” egyetemekben az oktatás-ku- 
2. táblázat: Az első, második, harmadik és negyedik generációs egyetemek néhány jellemzője Some characteristics of the first, second, third and fourth generations of universities

\begin{tabular}{|c|c|c|c|c|}
\hline Megnevezés & $\begin{array}{l}\text { Első generációs } \\
\text { egyetemek }\end{array}$ & $\begin{array}{c}\text { Második generációs } \\
\text { egyetemek }\end{array}$ & $\begin{array}{c}\text { Harmadik generációs } \\
\text { egyetemek }\end{array}$ & $\begin{array}{c}\text { Negyedik generációs } \\
\text { egyetemek }\end{array}$ \\
\hline Cél & Oktatás & Oktatás és kutatás & $\begin{array}{l}\text { Oktatás, kutatás és } \\
\text { tudáshasznosítás }\end{array}$ & $\begin{array}{l}\text { Oktatás, kutatás, } \\
\text { felelősségteljes } \\
\mathrm{K}+\mathrm{F}+\mathrm{I}, \\
\text { tudáshasznosítás, } \\
\text { proaktív } \\
\text { gazdaságfejlesztés }\end{array}$ \\
\hline Szerep & Az igazság védelme & $\begin{array}{l}\text { A természet } \\
\text { megismerése }\end{array}$ & Értékteremtés & $\begin{array}{l}\text { Helyi gazdasági } \\
\text { motor szerepe, } \\
\text { stratégiai } \\
\text { iránykijelölés }\end{array}$ \\
\hline Létrehoz & Szakembereket & $\begin{array}{l}\text { Szakembereket és } \\
\text { tudósokat }\end{array}$ & $\begin{array}{l}\text { Szakembereket, } \\
\text { tudósokat és } \\
\text { vállalkozókat }\end{array}$ & $\begin{array}{l}\text { Szakembereket, } \\
\text { tudósokat, } \\
\text { vállalkozókat, } \\
\text { versenyképes helyi } \\
\text { gazdaságot }\end{array}$ \\
\hline Nyelv & Latin & Nemzeti & Angol & $\begin{array}{l}\text { Többnyelvü } \\
\text { (nemzeti és angol) }\end{array}$ \\
\hline Menedzsment & Kancellár & $\begin{array}{l}\text { Részmunkaidős } \\
\text { tudósok }\end{array}$ & $\begin{array}{l}\text { Professzionális } \\
\text { menedzsment }\end{array}$ & $\begin{array}{l}\text { Professzionális } \\
\text { menedzsment és } \\
\text { helyi szakemberek }\end{array}$ \\
\hline
\end{tabular}

Forrás: Wissema (2009) alapján saját szerkesztés.

tatás-tudáshasznosítás hármason kívül célként megjelenik a helyi gazdaság tudatos, tervezett, jövőorientált fejlesztése. Ebben a modellben az egyetem a gazdaság katalizátora és motorja egyben, kiemelt szerepe van a stratégiai irányok kijelölésében. Nemcsak a szakemberek, tudósok, vállalkozók képzésében, hanem azok közegének formálásában is részt vesz. Egy „,negyedik generációs” egyetem esetében szükségessé válhat a több nyelven való operatív működés az összetett, határokon átnyúló kooperációk, hálózati kapcsolatok jelenléte miatt. A legfőbb stratégiai és operatív teendőkért professzionális menedzsment felel, azonban ebben a munkában fontos szerepet kapnak a lokális gazdasági viszonyokat jól ismerő, gazdaságfejlesztésben jártas helyi szakemberek.

\section{Egy sikeres „negyedik generációs” egyetem építőkövei és jellemzői}

Az egyetemek versenyképességi szerepének, potenciális gazdaságfejlesztési hatásainak, gazdasági-társadalmi környezetének ismeretében kísérletet teszünk a sikeres „negyedik generációs” egyetem modelljének létrehozására. 
A nemzetközileg sikeres egyetemek ismérvei funkciónként megadhatóak, azonban eltérő módszertan szerint. A világon jelenleg publikált felsőoktatási rangsorok saját szempontrendszerük szerint határozzák meg, hogy mi alapján tekintik sikeresnek az egyetemeket, azonban ezek jellemzően az oktatási és kutatási szempontra fókuszálnak. Ebből következően az első és második generációs funkciókhoz tartozó sikerességi faktorok a nemzetközi felsőoktatási rangsorokból egyértelműen leszűrhetők. A harmadik misszióhoz tartozó sikerességi faktorok a sikeres egyetemek stratégiáival közvetetten szintén megragadhatók.

E logikára támaszkodva empirikus felmérést végeztünk annak érdekében, hogy a nemzetközileg sikeres egyetemek sikerességi faktorait a három generációhoz tartozó funkciókkal írjuk le. Szekunder kutatásunk során 6 nemzetközi egyetemi rangsor ${ }^{1}$ kritériumrendszerét és indikátorkészletét tekintettük át abból a szempontból, hogy az egyes rangsorok mi alapján tekintenek sikeresnek egy-egy egyetemet. Tekintettel arra, hogy e rangsorok módszertana döntően az első és második generációs jegyek alapján rangsorol, a harmadik generációs funkciókhoz tartozó sikerességi faktorok feltárása e rangsorokból nem lehetséges. A harmadik generációs jellemzőket kutatásunk második fázisában tártuk fel, amikor is a nemzetközileg sikeres egyetemek (összesen 22 egyetem) tevékenységét és stratégiáját vettük górcső alá, és rendszereztük a harmadik generációs funkciók szerint. ${ }^{2}$

Az empíria eredményeire, valamint a „negyedik generációs” egyetem fentebb részletezett gondolatkísérletére támaszkodva kísérletet tettünk arra, hogy rendszerbe foglaljuk a "negyedik generációs” egyetem sikerességi faktorait (3. ábra). A modell alapját az egyetemi kontextusba helyezett rombuszmodell képezi, hiszen a helyi gazdaságba és társadalomba való beágyazódás a modern egyetem sikerességének szükséges, de nem elégséges előfeltétele. Ez alapozza meg az egyetem hatékony mủködését, az egyetem fenntarthatóságát és rentabilitását biztosító pénzügyi forrásoktól kezdve a magasan kvalifikált humán erőforrásokon át az infrastrukturális keretekig.

Az alapon álló két pillér az egyetemek klasszikus funkcióinak tekinthető oktatás-kutatás, valamint a harmadik-negyedik misszió. E két oszlopban kapnak helyet a legjelentősebbnek vélt építőkövek, melyek az egyetem eredményes működését segítik elő abban az esetben, ha azokat a múködési keretbe integrálják. Az oktatási és kutatási pillér, továbbá a harmadik-negyedik missziós pillér modellünkben egyaránt építőkövekből áll össze, melyek úgy jöttek létre, hogy kutatásunkban összevontuk a szekunder kutatás során feltárt azon változókat (összesen 59 változóval dolgoztunk), amelyek a modell keretei között hasonlóságot mutattak. Fontos megemlíteni, hogy az ily módon létrejött építőkövek az egyes pilléreken belül nem hierarchikus felépítésűek.

Az oktatási és kutatási pillér első építőköve a nemzetköziség/mobilitás, a mobilitáson belül pedig beszélhetünk hallgatói, kutatói és oktatói mobilitásról. A nemzetközivé válással összefüggésben egy „negyedik generációs” egyetemnek nagyban támogatnia kell a hallgatói mobilitást. Jelentős kapcsolati hálóval 
3. ábra: Egy nemzetközileg sikeres, a helyi gazdaság és társadalom igényeit kielégítő egyetem modellje Model of an internationally successful university that supplies the needs of local economy and society

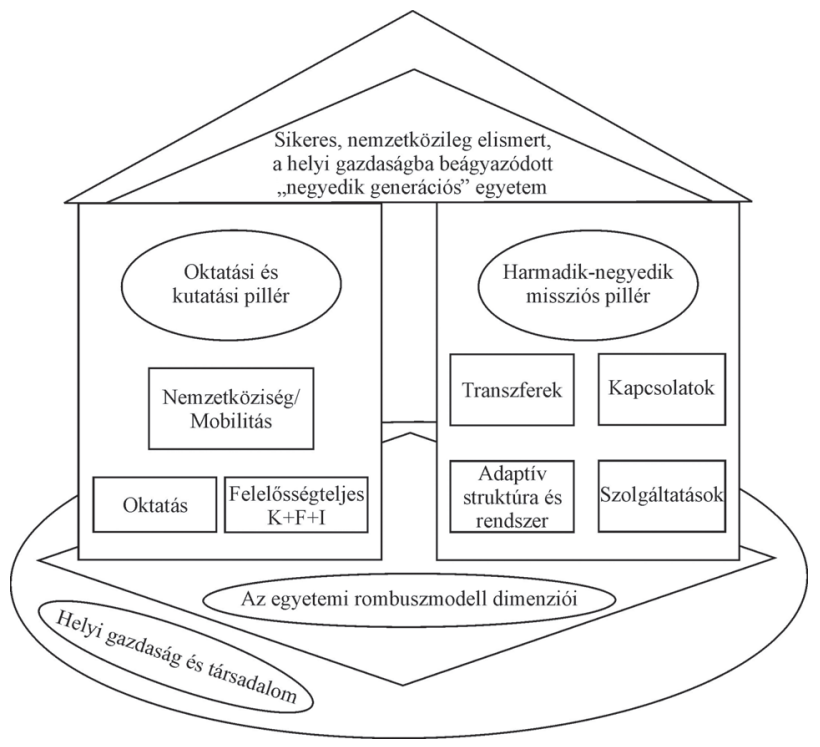

kell rendelkeznie, mely által diákjai számára mobilitási programokat biztosíthat megfelelő anyagi támogatással, ugyanakkor nyitottnak kell lennie külföldi hallgatók fogadására is a világ bármely tájáról. Ugyanezen szempontoknak kell érvényesülnie abban az esetben, amikor az adott egyetem a hazai, valamint nemzetközileg elismert kutatók, oktatók, professzorok meghívását és fogadását szervezi. A nemzetköziség kritériuma egyértelmüen leszürhető a nemzetközi rangsorok indikátorkészletéből, ezért indokoltnak tartjuk külön sikerességi faktorként való szerepeltetését.

A pillér második eleme az oktatás, melynek fontos eleme a képzési portfólió, mely számos tényezőt foglalhat magában, mint például BA/BSc-, MA/MSc-, PhDképzések, felnőttképzés, felzárkóztatási programok, valamint a képzésfejlesztés. Az oktatás mint sikerességi faktor ugyanakkor nagyon fontos minőségi tényezőkre is koncentrál (pl. figyelembe veszi az adott intézmény díjazottainak számát, az oktatási hírnévfelmérés eredményeit, a kiadott diplomák, fokozatok számát stb.).

A pillér harmadik eleme a kutatás. Az oktatás mellett a kutatás is az egyetemek alapvető feladataihoz tartozik, nélkülözhetetlen a felsőoktatási intézmények életében. Itt fontos megemlíteni, hogy elengedhetetlen szerepe van a nemzetközi szinten is méltatott tudományos folyóiratokban való publikálásnak, a nemzetközi konferenciákon való előadások tartásának, az idézettségnek, az akadémiai hírnévnek stb. Módszertani szempontból fontos kiemelni, hogy olyan kutatásokat veszünk számba, melyek nem külső megrendelőnek készülnek (utóbbiakat a harmadik missziós tevékenységek közé soroljuk). 
Ezen a ponton kell kiemelnünk, hogy a modern negyedik generációs egyetemeknek nemcsak a kutatás-fejlesztés és innováció magas minőségére kell figyelemmel lenniük, hanem az előző fejezetben bemutatott felelősségteljes innováció eszméjének regionális szintü gyakorlati alkalmazására is. Kiemelten fontos az egyetemi elkötelezettség a jövő megóvása érdekében, ami a tudomány és innováció jelenbeli felelősségteljes kezelésével valósulhat meg. Ez a tényező a modern negyedik generációs egyetemek egyik legfontosabb funkciója lehet annak ellenére, hogy mindez nem az egyetemi rangsorokból következő sikerességi faktor.

A harmadik-negyedik missziós pillér első építőköve a transzferek. Ezen belül megkülönböztethetjük a tudástranszfert és a technológiatranszfert. A tudástranszfer megközelítése esetünkben a tacit (hallgatólagos) tudásra, míg a technológiatranszfer a kodifikált tudásra, információáramlásra irányul.

A pillér második építőköve a kapcsolatok, melyen belül megkülönböztethetünk belső és külső kapcsolatokat. Belső kapcsolatokon főként a hazai szintű (nemzetgazdasági szintű) gazdaság-kormányzat-egyetem kapcsolatrendszert értjük (triple helix modell). Külső kapcsolatokon a nemzetközi hálózatépítést vagy együttmüködéseket értjük, szintén a gazdaság-kormányzat-egyetem között. Egy modern egyetem számára előnyös lehet, ha párhuzamosan alakít ki hazai és nemzetközi együttműködéseket, legyen az akadémiai vagy üzleti irányultságú. Lényeges cél, hogy a modern felsőoktatási intézmény jelentős gazdasági hatást indukáljon. Egy „negyedik generációs” egyetem esetében fontos, hogy a kialakult kapcsolatoknak, innovációs együttmüködéseknek jelentős gyakorlati haszna legyen, valós problémákra adjon választ. Napjaink állandóan változó világában elengedhetetlen a folyamatos innováció, az új ötletek, megoldások a vállalkozások sikereinek zálogai lehetnek. A kiváló kutatás és állandó innovációs tevékenység által az egyetem bekapcsolódhat a térség vállalatainak támogatásába, fejlesztésébe.

A pillér harmadik építőköve az adaptív struktúra és rendszer. Ezt úgy definiálhatjuk, mint egy olyan rugalmasan alkalmazkodó szervezeti felépítést az intézmény tervezése, szervezése, vezetése, ellenőrzése szempontjából, mely azt vizsgálja, hogy hogyan tudna az egyetem a leghatékonyabban müködni térségében. Ide tartozik a helyi munkaerőpiac képzési igényeire, a helyi gazdasági szféra kutatási igényeire való reagálás, a helyi gazdaságfejlesztési irányok formálása stb. Az adaptív struktúra tehát olyan menedzsmentorientált vezetést mutat be, mely proaktív módon fóként a helyi adottságok kiaknázására épít, és amely innovatív, rugalmas szervezeti kultúrában müködik. Ez a szemlélet markánsan alapoz a helyi hálózatok kiépítettségére és a fentebb részletezett „negyedik generációs" funciókra.

A harmadik-negyedik missziós pillér negyedik építőköve a szolgáltatások, melynek keretében új bevételszerzési lehetőségek nyílhatnak az egyetemek számára, emellett az intézmény hozzájárulhat a helyi gazdaság fejlesztéséhez, induló és müködő vállalkozások fejlesztésének támogatásához, például az egyetemek tanácsadási tevékenységével (gazdaság- és vállalkozásfejlesztési szolgáltatások, főként külső megbízó számára nyújtott kutatás-fejlesztési tevékenység stb.). 
A modell építőköveinek legfelső eleme az egyetemi stratégiai célt szemlélteti, vagyis annak elérését, hogy maga az egyetem nemzetközileg is elismert, a helyi gazdaságba integrálódott „negyedik generációs” egyetemmé váljon. A modern egyetemek víziója a nemzeti és globális jólét elérése és fenntartása, az imént vázolt építőelemek megvalósításával. A sikeres, nemzetközileg elismert, a helyi gazdaságba beágyazódott „negyedik generációs” egyetem mint vízió a „Mit?” kérdésre válaszol, azonban a „Hogyan?” kérdés nyitott marad. Ezt úgy tudjuk feloldani, hogy a végső stratégiai célt minden esetben leképezzük az adott helyi gazdaság és társadalom sajátosságainak megfelelően, azaz az egyetemek által létrehozott hozzáadott értékeket a lokális térség adottságaihoz igazítjuk.

\section{Összegzés}

Jelen tanulmányban áttekintettük és rendszereztük az egyetemek azon aktív és passzív tevékenységeit, amelyek egy térség versenyképességének javítását szolgálják. Megvizsgáltuk az egyetemek lehetséges gazdaságfejlesztési hatásait, melyek input- és outputoldali tényezőket, hosszú és rövid távú hatásokat egyaránt érintettek. Ezután elemeztük az egyetemek társadalmi-gazdasági környezetét. Körüljártuk egy érdekes gondolatkísérlet, a „negyedik generációs” egyetemek mibenlétét, és megpróbáltuk mindezeket az egyetemi generációk tudományosan igazolt fogalomrendszerébe helyezni. Felvázoltuk a modern egyetemek rombuszmodelljét, végül ismertettünk egy egyetemi modellt, mely tartalmazza azon építőköveket, sikerességi faktorokat, melyek egyrészt hozzájárulhatnak ahhoz, hogy az egyetemek a lokális térben rejlő lehetőségeket optimalizálva globális sikerre tegyenek szert, másrészt az ilyen egyetemek e keretet kitöltve képesek lehetnek arra is, hogy befolyásolják, növeljék az adott régió versenyképességét.

Tanulmányunk közvetett célja volt az is, hogy a témával foglalkozó kutatók számára további kutatásokhoz nyújtson alapot, és a „negyedik generációs” egyetemek vizsgálata - az elmélet alátámasztása, cáfolata - a továbbiakban folytatódjék. Ahogy tanulmányunkban hangsúlyoztuk, a "negyedik generációs” egyetemek témakörét és elnevezését sem tekintjük még tudományosan alátámasztott tételnek, tartalmát tekintve inkább a triple helix modell egyetem helixének hangsúlyosabb szerepéről beszélhetünk, hiszen az egyetem ez esetben szükségszerüen domináns szerepű a helyi gazdaság többi szereplője között.

Kérdés, hogy a tanulmányban tárgyalt „negyedik generációs” funkciók mint nóvumok elegendőek-e ahhoz, hogy generációváltásról beszéljünk. Tény, hogy az első és a második, valamint a második és a harmadik generációs egyetemek közötti „ugrás” jóval meghatározóbb volt, mint amelyről a tanulmányunkban értekeztünk. Ebben a megközelítésben elképzelhető, hogy valójában egy „három és feledik” generációs egyetemről kellene beszélnünk. A kérdés az, 
hogy van-e egyáltalán lehetőség az előző két generációváltásnál tapasztalt határozott ugrásokra, és ha igen, akkor az mely funkcióra vonatkozhat. Ha további missziókkal bővül az egyetem, nevezhetjük-e ezt a szó klasszikus értelmében vett egyetemnek vagy inkább olyan „hibrid” intézményről beszélünk, mely a megváltozott gazdasági, környezeti, társadalmi igények következtében adaptálódott a térség kihívásaihoz, elvárásaihoz.

A téma tehát a fentiekhez hasonló kutatási kérdéseket vethet fel, azonban megítélésünk szerint a tanulmányban tárgyalt „negyedik generációs” logika nagymértékben előmozdíthatja gondolkodásunkat az egyetemközpontú gazdaságfejlesztésről, különös tekintettel az elmaradott térségekben.

\section{Köszönetnyilvánítás}

A kutatás a TÁMOP 4.2.4.A/2-11-1-2012-0001 azonosító számú „Nemzeti Kiválóság Program - Hazai hallgatói, illetve kutatói személyi támogatást biztosító rendszer kidolgozása és működtetése konvergencia program" címü kiemelt projekt keretében zajlott. A projekt az Európai Unió támogatásával, az Európai Szociális Alap társfinanszírozásával valósul meg.

\section{Jegyzetek}

1 Academic Ranking of World Universities, Times Higher Education World University Rankings, Quacquarelli Symonds, Scimago Institutions Rankings, University Ranking by Academic Performance, Ranking Web of Universities.

2 Az egyetemek stratégiáinak feltérképezése Molnár Gabriella munkája. A Zuti Bence és Molnár Gabriella által a nemzetközileg sikeres, a helyi gazdaság és társadalom igényeit kielégítő egyetem modelljéről írt dolgozat a XXXI. Országos Tudományos Diákköri Konferencia Közgazdaságtudományi Szekciójában a Regionális gazdaságtan II. tagozatban II. helyezést ért el.

\section{Irodalom}

Arbo, P., Benneworth, P. (2007): Understanding the regional contribution of higher education institutions: A literature review. OECD, Paris (Education Working Paper; 9.)

Bajmócy Z. (2006): Egyetemi üzleti inkubáció lehetőségei elmaradott térségekben. Tér és Társadalom, 3., 31-47.

Bajmócy Z., Lukovics M., Vas Zs. (2009): A subregional analysis of universities' contribution to economic and innovation performance. University of Košice, Košice

Benneworth, P., Dawley, S. (2005): Managing the university third strand innovation process? Developing innovation support services in regionally engaged universities. Knowledge, Technology, \& Policy, 3., 74-94. 
Benneworth, P., Sanderson, A. (2009): The regional engagement of universities: Building capacity in a sparse innovation environment. Higher Education Management and Policy, 1., 131-148.

Carayannis, E. G., Campbell, D. F. J. (2012): Mode 3 knowledge production in quadruple helix innovation systems. Twenty-first-century democracy, innovation, and entrepreneurship for development. SpringerBriefs in Business, 7., 1-63.

Carayannis, E. G., Campbell, D. F. J. (2014): Developed democracies versus emerging autocracies: arts, democracy, and innovation in quadruple helix innovation systems. Journal of Innovation and Entrepreneurship, 1.

Carayannis, E. G., Rakhmatullin, R. (2014): The quadruple/quintuple innovation helixes and smart specialisation strategies for sustainable and inclusive growth in Europe and beyond. Journal of the Knowledge Economy, 2., 212-239.

Chatterton, P., Goddard, J. (2000): The response of higher education institutions to regional needs. European Journal of Education, 4., 475-496.

Clark, B. R. (1998): Creating entrepreneurial universities: Organizational pathways of transformation. Pergamon, Oxford

Clark, B. R. (2001): The entrepreneurial university: New foundations for collegiality, autonomy, and achievement. Higher Education and Management, 2., 9-24.

EC (2013a): Responsible research and innovation (RRI), science and technology. European Commission, Brussels

EC (2013b): Options for strengthening responsible research and innovation. European Commission, Brussels

Etzkowitz, H. (2002): The triple helix of university-industry-government. Implications for policy and evaluation. Science Policy Institute, Stockholm

Etzkowitz, H. (2008): The triple helix: Industry, university, and government in innovation. Routledge. New York

Etzkowitz, H., Leydesdorff, L. (2000): The dynamics of innovation: from national systems and "mode 2" to a triple helix of university-industry-government relations. Research Policy, 2., 109-123.

Eurostat (2014): GDP per capita in the EU in 2011: seven capital regions among the ten most prosperous. Eurostat, Brussels

Florida, R. (1995): Toward the learning region. Futures, 5., 527-536.

Gibb, A. A., Haskins, G., Robertson, I. (2013): Leading the entrepreneurial university: Meeting the entrepreneurial development needs of higher education institutions. In: Altmann, A., Ebersberger, B. (eds.): Universities in change: managing higher education in the age of globalization. Springer, New York, 9-45.

Goddard, J., Pukkaa, J (2008): The engagement of higher education institutions in regional development: An overview of the opportunities and challenges. Higher Education Management and Policy, 2., 11-41.

Goldstein, H. A., Renault, C. S. (2004): Contributions of universities to regional economic development: A quasi-experimental approach, Regional Studies, 7., 733-746.

Grosz A., Rechnitzer J. (szerk.) (2005): Régiók és nagyvárosok innovációs potenciálja Magyarországon. MTA RKK, Pécs, Győr

Holbrook, J. A., Wolfe, D. A. (2002): Knowledge, clusters and regional innovation: Economic development in Canada. In: Holbrook, J. A., Wolfe, D. A. (eds.): Knowledge, clusters and learning regions. School of Policy Studies, Queen's University. Kingston

Imreh-Tóth M., Lukovics M. (2014): Egyetemközpontú vállalkozásfejlesztés elmaradott térségben: negyedik generációs egyetemi funkciók? Marketing \& Menedzsment, 2., 43-56.

Kitagawa, F. (2005): Entrepreneurial universities and the development of regional societies: A spatial view of the Europe of knowledge. Higher Education Management and Policy, 3., 65-89.

Lengyel B. (2004): Egyetem - gazdaság - kormányzat együttműködése: a Triple Helix modell a gyakorlatban. In: Lengyel I. (szerk.): A Szegedi Tudományegyetem lehetőségei a tudásalapú helyi gazdaságfejlesztésben. Kutatási háttéranyagok V. kötet. K+F és egyetemek az Európai Unióban. Szegedi Tudományegyetem, Szeged, 1-31.

Lengyel I. (2000a): A regionális versenyképességről. Közgazdasági Szemle, 12., 962-987.

Lengyel I. (2000b): Porter-rombusz: a regionális gazdaságfejlesztési stratégiák alapmodellje. Tér és Társadalom, 4., 39-86.

Lengyel I. (2003): Verseny és területi fejlődés: térségek versenyképessége Magyarországon. JATEPress, Szeged 
Lengyel I. (2004): Egyetemek szerepe a helyi gazdaságfejlesztésben. In: Lengyel I. (szerk.): A Szegedi Tudományegyetem lehetőségei a tudásalapú helyi gazdaságfejlesztésben. Kutatási háttéranyagok IV. kötet. Egyetemek szerepe a helyi gazdaság- és vállalkozásfejlesztésben. Szegedi Tudományegyetem, Szeged, 1-54.

Lengyel I. (2008): „Távolság versus közelség” dilemma az ipari-egyetemi kapcsolatokon alapuló tudásalapú helyi gazdaságfejlesztésben. In: A gazdasági környezet és a vállalati stratégiák. A IX. Ipar- és Vállalatgazdasági Konferencia előadásai. Szeged, 551-562.

Lukovics M. (2010): Az egyetemek lehetséges szerepe a régiók versenyképességének javitásában. Kézirat. SZTE GTK, Szeged

Owen, R., Macnaghten, P., Stilgoe, J. (2012): Responsible research and innovation: From science in society to science for society, with society. Science and Public Policy, 6., 751-760.

Pawlowski, K. (2009): The 'fourth generation university' as a creator of the local and regional development. Higher Education in Europe, 1., 51-64.

Sutcliffe, H. (2013): A report on responsible research and innovation. Matter, London

Vilmányi. M. (2011): Egyetemi-ipari együttműködések a kapcsolatmarketing nézőpontjából. Vezetéstudomány, 1., 52-63.

Von Schomberg, R. (2013): A vision for responsible research and innovation. In: Owen, R., Bessant, J., Heintz, M. (eds.): Responsible innovation: Managing the responsible emergence of science and innovation in society. John Wiley, Chichester

Wissema, J. G. (2009): Towards the third generation university. Managing the university in transition. Edward Elgar, Cheltenham

Wright, M., Clarysse, B., Lockett, A., Knockaert, M. (2008): Mid-range universities' linkages with industry: Knowledge types and the role of intermediaries. Research Policy, 8., 1205-1223. 